Матеріали Всеукраїнської науково-практичної конференчії «Актуальні питання діагностики, лікування, рачіональної фармакотерапії, диспансеризачії та реабілітації в практиці сімейного лікаря»

DOI

\title{
ОСОБЛИВОСТІ КОРЕКЦІЇ ПОКАЗНИКІВ ЧЕРВОНОЇ КРОВІ ПРИ ХРОНІЧНИХ ЮВЕНІЛЬНИХ АНОМАЛЬНИХ МАТКОВИХ КРОВОТЕЧАХ
}

○В. Ю. Добрянська, Л. В. Багній, С. М. Геряк, В. Д. Якимчук, Г. В. Колочун, Н. І. Багній, З. Я. Мавдрік, В. М. Хіночик

ДВНЗ «Тернопільський державний медичний університет імені І. Я. Горбачевського МОЗ України»

Аномальні маткові кровотечі у підлітковому періоді, за даними літератури, складають понад 20 \% усіх гінекологічних захворювань дівчаток. Тривала чи значна за об'ємом менструація призводить до розвитку залізодефіцитної анемії як крайнього ступеня прояву дефіциту депонованого заліза. Тому сучасні принципи лікування аномальних маткових кровотеч ювенільного віку мають на меті зупинку кровотечі (гемостатиками, гормональний чи хірургічний гемостаз), її профілактику шляхом нормалізації менструального циклу, в тому числі відновлення депо заліза і рівня гемоглобіну в крові. У кожному разі появи кровотеч у підлітковому віці, їх лікування та спостереження повинно розпочинатися в умовах стаціонару.

Метою нашого дослідження було вивчення ефективності корекції показників червоної крові у дівчаток з ювенільними аномальними матковими кровотечами лікарським засобом зі збалансованим вмістом заліза, цинку і життєво важливих вітамінів Ферсинол-Z.

3 цією метою обстежено 48 дівчаток віком 12-15 років, які перебували на стаціонарному лікуванні з приводу АМК ювенільного віку. Прояви альгодисменореї діагностували у 44 \% (21) обстежених. Дані порушення тривали в середньому $(7,2 \pm 0,9)$ місяці. При поступленні в стаціонар скарги на тривалу кровотечу, яка не зупинялася протягом останніх 8-10 днів, висловлювали 54 \% (26) пацієнток, 46 \% (22) - на великий об'єм крововтрати протягом останніх 6-8 год.

у обстежених нами дівчаток-підлітків був знижений рівень гемоглобіну до $(77,9 \pm 9,5)$ г/л, гематокриту до $(28,5 \pm 1,8)$, кольорового показника - до $(0,8 \pm 0,1)$, та збільшення кількості ретикулоцитів до $(1,6 \pm 0,7) \%$, що свідчить про наявність хронічної анемії середнього ступеня з помірно зниженою регенераторною здатністю. Хронічні кровотечі, що мали місце у обстежених нами дівчаток, призвели до виснаження депо-запасів заліза в організмі. Про це свідчить підвищення рівня загальної залізозв'язувальної здатності плазми до $(86,3 \pm 6,3)$ мкмоль/л та трансферину до $(5,1 \pm 0,8)$ г/л.

Для корекції анемічних проявів усім дівчаткам призначали Ферсинол Z, що у своєму складі містить збалансований комплекс заліза (у вигляді сульфату заліза 150 мг, що еквівалентно 50 мг $\mathrm{Fe}^{2+}$ ) протягом наступних 3-6 місяців.

При повторному обстеженні дівчаток через 6 місяців після проведеного лікування рівень гемоглобіну підвищився до $(119,4 \pm 8,1)$ г/л, гематокриту до $(38,1 \pm 2,1)$, кольоровогопоказника-до $(1,0 \pm 0,2)$, сироваткового заліза - до $(15,3 \pm 1,2)$ мкмоль/л. Про відновлення запасів депонованого заліза свідчило зниження загальної залізозв'язувальної здатності плазми до $(69 \pm 5,2)$ мкмоль/л та рівня трансферину - до $(3,9 \pm 0,9)$ г/л.

Таким чином, для корекції залізодефіцитного стану та анемії, що супроводжує хронічні ювенільні аномальні маткові кровотечі, можна рекомендувати Ферсинол Z, який дає можливість не лише поновити запаси заліза в організмі та швидко відновити рівень еритроцитів та гемоглобіну, але й, завдяки наявності в його складі цинку та вітамінів, здатний нормалізувати функціональний стан клітинних та внутрішньоклітинних мембран і, таким чином, відновити їх метаболічну активність.

Висновки. Залізодефіцитна анемія при хронічних ювенільних аномальних маткових кровотечах потребує обов'язкової корекції комплексними залізовмісними засобами на основі солей заліза в формі сульфатів, такими як Ферсинол Z. Вони мають високу біодоступність, добре розчиняються у воді та ефективно підвищують біодоступність заліза в присутності вітамінів групи В, цинку і фолієвої кислоти. 